\title{
Development Within a Religious Ontology? The Argument from Islamic Dharma
}

\author{
Fernande W. Pool ${ }^{1}$ \\ Published online: 4 December 2019 \\ (C) The Author(s) 2019
}

\begin{abstract}
Drawing on long-term ethnographic research with Muslims in India, this article suggests that religion should not (only) be understood as a sub-category of development but as an integral part of the meta-ontology based on which one should engage with development initially. Value-driven development implies a normative view of society, and a 'more human' society is at the core of worthwhile development. For the research participants, their ontological conceptions (notions of what being human means) and the ethical autonomy to deliberate on a normative view of life and society are embedded in the Islamic dharma. To approach religion as only a sub-category in an otherwise secular development framework marginalises these, and probably many other, religious life experiences and ontological notions from the outset. Instead, secular and religious ontologies should be considered at par in an inclusive dialogue on worthwhile development.
\end{abstract}

Keywords Religion · Development ethics · Human development · Secularism · Islam · South Asia

\section{Resume}

L'article s'appuie sur des recherches ethnographiques menées sur le long terme auprès de Musulmans en Inde pour suggérer que la religion ne devrait pas être envisagée (uniquement) comme une sous-catégorie du développement, mais comme une partie intégrante de la méta-ontologie sur laquelle il faudrait se baser en amont de toute interaction avec le développement. Un développement fondé sur les valeurs implique une vision normative de la société, et une société «plus humaine» est au cœur d'un développement qui a du sens. Pour les participants à la recherche, leurs conceptions ontologiques (les considérations sur ce que signifie qu'être humain) et leur autonomie éthique pour formuler une vision normative de la vie et de la société sont intégrées dans le dharma islamique. Le fait d'appréhender la religion comme une simple souscatégorie d'un développement par ailleurs séculier marginalise d'entrée de jeu ces

Fernande W. Pool

pool@iss.nl

1 Institute of Social Studies, Kortenaerkade 12, 2518 AX The Hague, The Netherlands

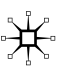


expériences de vie religieuse et ces notions ontologiques, ainsi que beaucoup d'autres probablement. Au lieu de cela, les ontologies devraient être considérées sur un pied d'égalité, qu'elles soient laïques ou religieuses, dans un dialogue inclusif sur un développement qui a du sens.

We had never seen such a display of discipline in the village. People stepped outdoors, peeked around trees, walked across paddy fields and climbed on rooftops to get the best view of the spectacle.

It was the arrival of the girl students from an Al Hilal mission school attending the opening ceremony of a new branch here in Joygram, ${ }^{1}$ a Muslim-majority village in rural West Bengal. The girls were brought in a rented passenger bus, which seemed to have been parked deliberately a few hundred meters from the school, and now the girls were walking (almost marching) in perfect rows of two towards the school, in batches according to class, all meticulously dressed in the same pale-blue churidars, with a pristine white scarf covering their hair.

A ripple of awe went through the village. It felt like this parade, with its organised aesthetics, was bringing order to the chaos of rural life in India. This was the future - the opportunity that lay within reach for the villagers, a world of order and cleanliness.

Muslim girls would become engineers, doctors, politicians. Muslims would no longer lag behind. Now also Bengali Muslims would be proper Muslims, on the right path. Now also Muslim Bengalis would become the civil Indian citizens they aspired to be; now they would earn the respect they deserved.

As made shockingly plain in the Sachar Committee Report (2006) and repeatedly afterwards in governmental reports and non-governmental evaluations, the educational levels of Muslims are far below the Indian national average. ${ }^{2}$ A variety of factors play a role, including, according to some, the unwillingness of Muslims to become modern educated citizens, and especially to allow for women to progress. ${ }^{3}$ The picture just sketched of the proud reception of a school aimed at educating girls to become engineers and lawyers suggests otherwise. What can the awe stirred by the Islamic mission school tell us about the values and aspirations of Muslim Bengalis? And what does that, in turn, tell us about appropriate approaches to wellbeing?

\footnotetext{
1 All names are pseudonyms, except for names of public persons and institutions that are not incriminated by the information shared.

2 In 2001, the officially recorded literacy rate of India's rural male Muslims was $79 \%$ compared with $91 \%$ of 'all others' (male); and that of rural female Muslims was $78 \%$ compared with $90 \%$ (female all others) (SCR 2006). A survey conducted in 2009-2010 showed that $18 \%$ of Muslims had matriculation level of education compared with 36\% of general Hindus (Shariff 2012). A survey in 2012 still showed a nearly 20\% illiteracy rate among rural Muslims in West Bengal (SNAP 2014).

3 Within South Asia, social scientists have observed institutionalised practices of discrimination against Muslims and forms of implicit victimisation in a variety of places (Jeffery and Jeffery 2006; Jeffrey et al. 2008; Khan 2007; Kirmani 2008; Williams 2011). There is ample literature on Muslims' marginalisation in India, whether this being economic and social marginalisation (Alam 2010; Hasan 2007), lack of political representation (Ansari 2006; Williams 2012), low levels of education and literacy (Alam and Raju 2007) or the particular double marginalisation of Muslim women (Hasan and Menon 2005).
} 
In addressing these questions, what can development thinkers and practitioners learn about the relationship between religion and development?

Until recently, development was primarily aimed at economic growth. Since the 1970s, in the wake of relentless growth and huge ecological degradation rather than decrease of inequality, a broader conception of development as comprising a set of social, economic, ecological and political processes is slowly gaining influence. The new paradigm, initiated by the basic needs approach, has wellbeing as its goal: an acknowledgement that an increase in gross domestic product (GDP) does not necessarily increase quality of life. Development studies were now to pay attention to such hard to measure elements as religion, as a controversial World Development special issue entitled 'Religion and Development' suggested in 1980. The 'pillars of human development' (Haq 1995) include not only wellbeing but also equity, empowerment and environmental sustainability; more recently Drydyk and Keleher (2018) have added human rights, cultural freedom and integrity as values that distinguish worthwhile development from undesirable maldevelopment.

Yet questions thereby arise regarding the normative underpinnings of the development project in theory and practice. In the capability approach, for instance, freedom (Sen 1999) and/or human dignity (Nussbaum 2010) are considered as ultimate values, provoking the question about what freedom and human dignity mean in different contexts. Over the last decades, scholars have debated the applicability and compatibility of this kind of normative position in a wide variety of geographical, cultural and religious contexts (Drydyk and Keleher 2018; Gough and McGregor 2007; Venkatesan and Yarrow 2012; Watene and Drydyk 2016; White 2015). Religion is now often recognised as an end in itself, but only as one dimension of wellbeing among others, within an otherwise secular framework, whereas this might not align with the lived reality.

Drawing on ethnographic data from India, it is hereby suggested that, for many people, religion may not be a sub-category of development but an integral part of the meta-ontology based on which they might engage with development to begin with. A 'more human' society (Lebret 1942 cited in Goulet 1995, p. 6) -a formulation which implies a normative view of life and society-is at the core of a worthwhile, value-driven development project (Crocker 1991; Khader and Kosko 2019). For religiously affiliated people, ontological conceptions (notions of what being human means) and a normative view of life and society (e.g. notions of freedom and human dignity) are often intimately bound up with or rooted in religious ideas. To approach religion as only a sub-category in an otherwise secular framework may marginalise religious life experiences and ontological notions from the outset.

For instance, if dignity and freedom are at the core of a development approach, such as in the capability approach, then a dialogue on their operationalisation should be informed by the ontological meaning of freedom and dignity in each local context, also when the source of meaning is religious. This is the starting point; meanings may then alter in the course of the dialogue, since religion is internally dynamic. Such a dialogue may result in a locally specific capability theory application within the guidelines of a universal capability approach. 
The paper's argument unfolds as follows: first some approaches to religion, wellbeing and development are discussed, and the proposed contribution to literature is further explained. The ethnographic setting of the present case study is then introduced: a Muslim-majority village (here called Joygram) in West Bengal, India, where the author undertook 18 months fieldwork. The narratives of development that emerge from the ethnography warrant a value-driven approach to development that goes 'beyond GDP'. It is then explained that the values driving development in Joygram, including conceptualisations of being human, are embedded in what the author calls the Islamic dharma: the locally specific all-encompassing ethics of justice and order to which religion - in this case Islam - is integral. So, if development is to be considered worthwhile, it has to be embedded in dharma, too. Moreover, first, dharma is fundamental for the local understanding of ethical autonomy, which in turn is indispensable for public reasoning on development issues; and second, dharma is considered to embrace all ethics, norms and values, so development outside this space would be reduced to purely technocratic and instrumental measures. The next section illustrates why this kind of embedded development is therefore closer to worthwhile development (as opposed to maldevelopment), using the example of the Islamic mission school introduced earlier.

This example also unveils limitations that religion-driven development may encounter. From the 1990s onwards, some scholars have suggested we should strive after 'alternatives to development' rather than seeking local compatibility with a development paradigm that remains problematic conceptually and practically (Cooper and Packard 1997; Escobar 1995; Ferguson 1990; Sachs 1992). The penultimate section disputes that there are pre-modern communities that could develop in isolation and argues instead that development dialogues ought to be guided by certain translocal commitments, as formulated for instance in the Universal Declaration of Human Rights, or in Martha Nussbaum's capabilities approach (2000, 2011). Without tools that guarantee the inclusion of all voices, certain (religious) leaders could occupy a monopoly on deciding what worthwhile development means.

In the final section, a discussion of how an inclusive pragmatic dialogue could strive after an overlapping consensus across the secular-religious binary is briefly initiated. If the ends of development are to be determined without undermining religious values, a religious tradition central values need to be identified through processes of internal reasoning that draw on a tradition's own critical resources (Nussbaum and Sen 1987; Nussbaum 2000). Conclusions section reflects on the anti-globalisation backlash that could result from the negative effects of an economy-focussed modernisation, but also on commitments to public goods, rooted in transcendental sources, that may offer hope for a harmonious, plural and more equal society in a globalised world.

\section{The Development Approach to Religion}

For much of the 20th century, the predominant view of culture and religion from a development perspective could be reduced to the following: problematic obstacles to modernisation and progress, potential drivers of development or harbourers of 
timeless values in a romantic projection of the 'good life' on 'traditional societies' (Deneulin and Rakodi 2011; White 2015).

Over the last few decades, religion has slowly gained a new position in development theory and practice. This 'rewriting of the secular script' (Deneulin and Bano 2009) is a result of the persistent presence of religion in the public sphere, refuting the secularisation thesis (Casanova 1994), the rise of political Islam (which has roots in the same Deobandi Islam discussed in the present work, but which has many varieties) and the recognition of the role of faith-based organisations in providing services (Clarke et al. 2007). Several studies, such as the influential World Bank study Voices of the Poor (Narayan et al. 2000), the multi-geographical Religion and Development Research Program and extensive studies of faith-based organisations (Clarke and Titterson 2016; Wilson 2014) demonstrate that, for many people across the world, religion cannot be reduced to a static set of doctrines but is often a more comprehensive, dynamic and internally contested social phenomenon that comprises everyday practices and ideas of what constitutes a good life (Bartelink and Buitelaar 2006; Clarke 2013; Deneulin 2006; Devine and Deneulin 2011; Devine and White 2013; Lunn 2009; Mesbahuddin 2010; Robeyns 2017; Tyndale 2006; White 2011; Wilson 2010). Within human development thinking, religion has been recognised as a dimension of wellbeing (Alkire 2000; Nussbaum 2000) and source of social action (Sen 2014) but also of potential violence (Nussbaum 2009; Sen 2006). Nussbaum more specifically argues for freedom of religion and religious affiliation, since 'religious conceptions of the good are [...] prominent among the reasonable conceptions that citizens may legitimately pursue' (Nussbaum 1999b, p. 107). In short, religion is 'not to be considered only as a significant force... but has to be engaged with in its entirety and not only to the extent that is conducive or detrimental to pre-defined development goals' (Deneulin and Bano 2009, p. 4).

These contributions open up a wider breadth of perspectives on the role of religion, which White and Deneulin (2009, p. 263) have helpfully summarised as follows: (1) religion is instrumental (positively or negatively) to achieving development goals; (2) religion influences people's values and what is considered legitimate development; (3) religious freedom is a fundamental human right that has to be respected; (4) religion is a constitutive part of people's wellbeing; and (5) religion is a political force that shapes society's economic, social and political structures.

Although this is a huge advance, and several of these points would appear to emerge from the author's own ethnography, a difficulty still persists; Most accounts consider religion as an optional dimension of wellbeing, but to position religion as an option would rely on a secular modern construction: the 'blank slate' human has the secular right to religious freedom and liberty of conscience (Asad 2003, p. 135). Even in approaches that go beyond a stark religion/secularism boundary, religion still predominantly appears as a category that can be isolated from other spheres of life, which is germane only to a Western Judeo-Christian genealogy. So some of the premises of the debate on religion in development fail to fully resonate with the lived reality on the ground. The lived reality in Joygram revolves around the Islamic 
dharma, the all-encompassing ethics of justice and order. ${ }^{4}$ Dharma is not limited to either religion or culture but encompasses both—and more. So, adding a sixth point of the role of religion, or perhaps better, a point that is overarching all other five, could be suggested: that religion can be an integral part of ontology, including what being human means. In this perspective, religion is not something that people can engage with but people engage with development from the religious ontology.

This perspective implies a cognitive turn to avoid the starting position of a discussion being still within the hegemonic secular ontology, just like refocussing from the aggregate to the individual and from functionings to capabilities requires a cognitive turn. It is no longer about taking religious values into account but acknowledging that the entire meaning of the world, the human and key values like freedom and dignity are for many or most people informed by a religiously inspired ontology. For instance secularism may be a worthy political ideology from a religious ontological standpoint, just as it may be from a non-religious ontological standpoint.

Having made this cognitive turn, religion is no longer an exotic 'other' to the secular; both are ontological positions including both immanent and transcendent sources. Religion is more a complex social phenomenon than a static and compartmentalised set of norms and symbols, even though some norms and values are strongly associated with a religion. We can build further on this reinterpretation of religion by suggesting that dynamic religious ideas of being and sociality interact with ideas of being and sociality outside of that discrete religion-if there ever was one. Moreover, religion is nothing special, yet central: it seems likely that every human being lives with ideas of being and sociality, whether consciously or not, and there are always transcendental elements, whether directly associated with a particular religion or not. ${ }^{5}$

In this sense, religion is just one dimension among others - but one integral part of a framework or ontology, not one sub-dimension that a secular framework may consider. This also means that the same universal guidelines can be operationalised from within religious and secular ontologies; a point elaborated in the penultimate section. First, the setting of the ethnography is introduced in more detail, and local perspectives on development are discussed, before moving on to a detailed ethnographic justification of the arguments brought forward so far.

\section{'We Don't Want Your Freedom'}

On a rainy Sunday afternoon during the relentless monsoon, I join my close friend Basir to pass time with his friends in the half-finished brick building that will soon function as the local health centre. It's a mixed group of men in their early thirties: most are Muslim, one Hindu, most dressed in modern jeans and shirt (including Basir), others in traditional Islamic attire; some are musicians, one is a wealthy

\footnotetext{
${ }^{4}$ It might sound surprising for outsiders that Muslims talk about dharma, usually considered a Hindu concept. Nevertheless, in the Bengali vernacular, it is customary to refer to any notion of ethics (from everyday custom to religious law) or anything related to the order of the macro-cosmos as dharma.

${ }^{5}$ The title of Maurice Bloch's 2008 article 'Why religion is nothing special but is central' has been paraphrased.
} 
entrepreneur, and Basir is the local representative of the political party in power in West Bengal. As usual, our conversation soon moves to matters of religion and politics. I recount the discussion in its messy, rich, and sometimes contradictory form here.

The men complain about the politics in the region, the fact that it has penetrated all aspects of life and the marginalisation of Muslims compared with Hindus, because ultimately, this is a 'Hindu-land' (Hindu-rastra). A related concern is that ordinary people have lost any sense of morality, having become 'loose characters', greedy and selfish, only out to fill their own pockets. To some extent, the lack of morality as well as the pervasiveness of (bad) politics is due to a lack of education, they claim, because uneducated people are dependent on political patronage, and they believe that a lack of education is the result of the abysmal financial situation of the state. But on a deeper level, the degeneration of society is attributed to a lack of fear for any higher authority: Muslims do not fear Allah anymore, Hindus no longer obey their moral authorities. Political leadership cannot be ascribed any moral authority, because politics is thoroughly corrupted: money and power breeds only more greed. Again, politics is corrupted because there is no god in the government: West Bengal was ruled by a communist coalition for over three decades, and they 'did not accept religion (dharma)'. Another reason why society is being depleted of morality is Western influence; Especially the norm of living separately in the West is astonishingly immoral: your parents have done everything for you when you were growing up, and then you do not care for them when they are old? Who will feed them rice?

At this point, most of the other men are moving outside to eat snacks a friend brought over on his motorbike. I invite Basir to talk about the position of women, in what becomes a heated conversation: he reckons women and men are equal because all humans are equal before Allah, yet there remains some fundamental difference. Increasingly irritated by my questioning, he concedes that in principle women from the village can seek employment, but that it would be better if they stayed home and stuck to their traditional duties of cooking, cleaning and care. I express increasing impatience with his refusal to grant women in his village the same freedom of choice as men, or in fact, as me, but he stubbornly repeats that, in the village, some difference just has to remain. Eventually, he angrily ends the conversation by saying 'we don't want your freedom', before joining his friends outside.

\section{Ambivalence About Development}

The conversation with Basir and his friends brings to light many of the ambiguities and ambivalences regarding development encountered time and again over the 18 months spent in Joygram. Two contrasting narratives of development can be synthesised; On the one hand, development is understood as economic growth, both in the sense of the nation's economic growth and in the sense of personal accumulation of money. National development is related to better secular education, improved 
infrastructure and increasing employment opportunities. This would allow people to have more disposable income, but at the moment they often feel stuck in a double bind: people are poor, and without money, they cannot afford good education or the bribes essential to access government services, seats and scholarships, protection and jobs. Even though money can be a good thing, as it stands, money has turned out to be a major corrupting agent. Money has not alleviated poverty for all but, instead, has created deeper inequalities, more greed and social fragmentation. Although none of the Joygramis discussed here are too poor to afford food, many of them expressed a sense of desperation. 'There is no development here' often denotes that the price of rice (on which the livelihood of these paddy farmers depends) has gone down, whereas the price of goods (fertilizer, food or commodities) has gone up.

On the other hand, development is talked about in relation to Islam or in terms of culture in a much broader sense: It means advancement in society, attaining substantive citizenship (enjoying civic rights, fulfilling civic duties of contributing to the nation, having access to spaces of influence, to benefits, etc.) and living in harmony, in a civilised manner-attaining civility. ${ }^{6}$

The state is held responsible for delivering development in the first sense: drawing on traditional notions of patronage, the state should take care of its people. The Joygram area has developed hugely over the last decades, and some aspects are unequivocally seen as positive: everyone, including the poor and the girls, can now go to school, and improved infrastructure means people can connect easily and quickly. However, somewhere along the way things went wrong in the eyes of most Joygramis, and there are two entangled critiques here.

Firstly, the purportedly modern government fails to live up to its ideals. Despite its achievements, there is a sense that development has ultimately stagnated after three decades of communist rule (1977-2011) bankrupted the state, and minorities are particularly left behind. Further, secularism 'isn't happening' in 'Hindustan', especially since the coalition of left wing parties took power. Note that Nehruvian secularism-dharmaniropekșatā in the vernacular-means 'neutrality of religion': instead of absence of religion, it denotes equal treatment and opportunities, and the safeguarding of harmony between all religious groups. ${ }^{7}$

Secondly, it is not just the modern state that is to blame for failing to deliver, modernity itself is inherently flawed. What worries Joygramis most is that the process of development is seen to go hand in hand with the problematic modernisation and Westernisation that the conversation above alluded to. Development has turned out to mean not an equally distributed increase in wealth but inclusion in exploitative capitalism, corrupt Realpolitik and a malfunctioning judicial system. Traditional networks of support and exchange are interrupted or undermined by the

\footnotetext{
6 These contrasting narratives and the ambiguity surrounding development are echoed in the research by White in rural India and Bangladesh as part of the DFID-funded Religions and Development Research Project led by the University of Birmingham. See e.g. White (2011).

7 See Bhargava (2010).
} 
market economy, while the state benefits meant to fill the gaps often fail to reach those in need.

Besides a corrupt economy and politics, modernisation has become synonymous with a total sense of moral degradation, not only in higher echelons of power but affecting every villager. This is captured with reference to a decline of dharma, the local ethics of justice and order. The secularism accompanying development has left politics and the economy without moral direction, and ordinary people do not follow dharma anymore. Therefore, one thing is always very clear: 'we don't want your freedom'. Because 'your' (Western) freedom is seen as unlimited (obhag shadinota) and hedonistic (sechacari), and leads to social fragmentation and egoistic behaviour. As is so often the case, women, supposedly harbouring timeless cultural and religious values, appear as the symbolic site for resistance against change, and my insistence on women's freedom makes Basir especially uncomfortable.

These fears for social fragmentation and moral degradation do not, however, eliminate a desire for modernisation. Joygrami Muslims still strive after the goods modernity has always promised but so far failed to deliver. Dharma does not stand in a mutually irreconcilable opposition to secular democracy or a capitalist economy; rather, it sets the moral foundations and limits: following dharma means treating Muslims and Hindus as equal humans in the deliverance of government services; it means being honest in business transactions; it means both rich and poor can access education. Yet the fear of losing dharma has led to the emergence of a counter-narrative: development as the 'upliftment' of the community from its 'backward' position in society is firmly embedded in modern interpretations of dharma cast in terms of Islamic reformism. Since the state cannot be trusted to either deliver development or provide moral guidance, and since Muslims, as the minority, are often blamed for their own underdevelopment, they have taken responsibility into their own hands to become better people, better Muslims, and hopefully, eventually, better modern citizens.

Muslims in Joygram express what some development theorists and practitioners have slowly began to discover since the 1970s: development has to be a valuedriven process, and 'more money' and 'more freedom' do not necessarily make one 'more human' with a better quality of life if not accompanied by a notion of justice and attention to other values. Moreover, the renewed emphasis on Islam, together with the rejection of Western notions of freedom, can give the impression that Muslims reject development and modernity altogether, and that their notions of what constitutes a valuable life are incompatible with universal development paradigms. Such an impression can be counteracted with use of more context and insight, which the ethnographic data here aims to offer. But a different view of Islamic reformism also requires the cognitive turn argued for above: the religious ontology can be the position from which to engage with development, including translocal development paradigms. Below, the sources of being human and ethical autonomy are discussed for Joygrami Muslims, which may represent the basis of dialogue on worthwhile development. 


\section{'There Is No Human Being Without Dharma'}

In Joygram, in contrast to in a genealogy of the liberal ideology, there is no conception of a human being as a sovereign agent emergent from a state of Nature. Instead, human beings emerge from social relationships, amongst which is the relationship of indebtedness to the divine (see Pool 2016). The very humanity of beings emerges from the acknowledgement of the eternal indebtedness to the creator-god for the gift of life. Subsequently, the being is made a 'human person' (there is no distinction between a pre-social human and a moral person) through bio-moral exchanges within a network of social relationships. As in other contexts where a relational ontology takes precedence over an individualist ontology, multiple networks of relationships forge individuals ontologically prior to and subsequently in tandem with individuals forging relationships. Islamic cosmogony is combined with South Asian holistic and relational ontology.

From a Joygrami perspective, a being in a state of Nature is an animal, not a reasonable moral subject. Nevertheless, everyone is equally endowed with the potential to become a human person and acquire human dignity. This potential is enacted when one acknowledges the gift of life from the divine and from one's social network. This acknowledgement positions the subject within dharma, and without dharma one would literally live like an animal, because this acknowledgement of indebtedness also activates the potential for ethical reflection; the freedom to choose how to live. In turn, ethical autonomy is shaped by the constraints of sociality and divine submission that generate it. Again, everyone has this ethical potential, not just Muslims or men: the Islamic dharma is just one amongst many expressions of dharma, and such distinctions are ultimately relatively insignificant human-made distinctions. The only human impossibility is to not have dharma, because that means that one rejects the gift of (human) life and rejects ethical potential. Dharma is thus intricately bound up with the fundamental human dignity of being able to live a life according to one's moral reflection.

The ethical potential of dharma far exceeds a narrow, reified notion of piety or religion, and is best captured in the concept gyan, which is usually translated as wisdom but is better understood as a dynamic situational practical reasoning, comparable to the Aristotelian concept phronesis, as it denotes the very ability to think autonomously and critically, and particularly to make moral assessments. To reiterate, the potential for gyan emerges, intricately bound up with a visceral habitus of faith (imān), in the process of becoming a human person within networks of sociality and in submission to the divine. Gyan is subsequently cultivated through a constant process of becoming, in interaction with others and through informal and formal moral teachings. Rather than being entirely constrained by static religious doctrine, it is gyan and a habitus of faith, together, that form the cornerstones of the Joygrami virtue ethics.

Questions concerning humanity and a good life are core to value-driven development, the only legitimate kind of development in the eyes of Joygramis. In the capability approach for instance, human dignity and freedom are both fundamental principles and ultimate values. In Joygrami folk theory, conceptions of the human 
and human dignity and the potential of moral action are deeply embedded in, indeed generated from, religious beliefs in the divine, which are in turn embedded in vernacular renderings of dharma. The same is true for gyan, the vernacular understanding of ethical freedom.

Ethical reflection and public deliberation on which values should drive and be achieved by development are crucial. Arguably, and explicitly recognised for example by Nussbaum, value-driven development therefore presupposes the capability to engage in (practical) reasoning and to make moral judgements. In secular thought, reason is often considered to be limited by religious or cultural tradition, and in this trend practitioners of Islam risk being stigmatised as irrational. But religion is not only potentially equally reasonable as secular ideology (cf. Nussbaum 1999b); in Joygram, ethical reasoning is enabled by sociality embedded in religious tradition. What is more, in drawing on gyan as the source of self-determination and conviction, reformist Muslims embrace a personhood that is at once deeply embedded in transcendence and in modernity. As such, and cultivating an 'alternatively modern' self, gyan disregards the binary of secular reason versus religious spirituality; And by extension, the 'human person' with gyan disregards modern differentiation of religion, politics and economy as separate spheres (Casanova 1994), let alone of development as pertaining only to the economic sphere, because gyan is also the enabler of any deliberation on human-centred development. In Joygram, the Islamic dharma is the overarching ontology from which to engage with development guidelines; elsewhere the content might be different. But equally, there are likely to be conceptions of the human and of ethical reason and freedom embedded in the religious or otherwise indigenous ontology, which would need to form the fundamental starting points for (deliberation on) value-driven development, rather than merely a dimension that people should be enabled to engage in.

\section{Islamic Mission Schools}

One contested area already mentioned is education. The mission schools are a helpful reference point: this grassroots educational initiative is an excellent indicator of local values and aspirations, and puts in sharp perspective the failures of the state to offer worthwhile development. However, this initiative also has its limitations.

As Basir and his friends pointed out, education could be the means to challenge political patronage, but by a lack of education they mean not only a lack of literacy but also a lack of moral education. Equally vice versa, mission school education is not only a site of religious teaching but also the site of the production of the modern citizen who has access to a wide range of opportunities. State schools are not considered to be of sufficient quality to actually increase the opportunities of this rural community, nor do they cultivate moral persons. The West Bengal state in particular has attempted to pacify the Muslim community call for better education by creating state-sponsored madrasas. However, these schools do not satisfy the aspirations: they are thought to be of even lower quality than regular government schools, and simply offering Arabic classes is not educating children to become moral citizens, let alone civilised modern citizens. 
In contrast, the mission schools are hugely popular in rural as well as urban areas in West Bengal, and they are successful in the creation of a Muslim middle class. These are educational institutions organised by the Muslim community. The phenomenon started with one Al-Ameen mission school in Howrah in 1986; it now has 32 branches across the state (Gupta 2009, pp. 126-166). The model has been copied by several other initiators, such as the Al-Hilal mission schools. The schools follow the curriculum of the West Bengal Board of Secondary Education complemented with a minimum of Islamic subjects. The most important and distinguishing aspect of the mission schools is not their curriculum but their strict regimen and discipline, and the seamless inculcation of an Islamic disposition within the larger project of the making of the modern Muslim citizen.

In January 2013, a girls-only branch of the Al-Hilal mission school opened in Joygram. The very presence of this school, and most evidently the speeches at the ceremonial opening day, reflected a particular discourse on the marginalisation of Muslims. Central to this discourse is the 'backwardness' of Indian Muslims and the need for progress so they become respectable and participatory citizens for the betterment of the Indian democracy as a whole. The schools are the hallmark of value-driven development: fusing dharma and modern civility, they are key to developing good culture among Muslims. Perhaps controversially, the religious education embedded in the syllabi of the mission schools may support particularly the less powerful in debating the priorities of development. The schools demonstrate that dharma is internally dynamic and can embrace a development policy that creates better opportunities for all, including women. Women are symbols of cultural continuity, but the mission schools convert girls into symbols also of progression and opportunity. They are able to do so because they appeal to gyan, embedded in dharma, they speak to actual anxieties and aspirations and they draw on alternative notions of modernity in the powerful discourse of Islamic reformism.

\section{Limitations of Religion as an Alternative to Development}

So far, it has been argued that a religiously inspired ontology has to be acknowledged as one valid framework for development debate and practice, and it has been suggested that the mission schools, inspired by Islamic reformism, offer a valid alternative to mainstream schools in West Bengal. This may appear to support the idea that religious grassroots initiatives form a valid alternative to development projects operating according to translocal guidelines. Post-development theorists suggest that current universal development paradigms betray a secular imperialism, and as such, they would undermine the value of indigenous culture, resulting in an inability or unwillingness to allow for genuine human dignity, human freedom and truly dynamic change within other than secular ways of being. But this view is too black and white and fails to appreciate the hermeneutical process and the more nuanced arguments. There are a number of reasons, then, why the argument put forward here differs from post-development theory, and why universal approaches, including theory and guidelines, remain important. 
Firstly, because of internal dynamics and porous boundaries, there is no pre-modern culture that can be protected from and elevated above modernity. In practices such as the mission schools, Islamic reformism operates not unlike secular modernisation projects, with the crucial difference that it is embedded in a religious-inspired ontology. These schools are therefore not an alternative to development, but offer a more nuanced alternative kind of modern development that Joygramis themselves aspire to. A post-development denial of this alternative modernity would be a denial of grassroots aspirations.

Second, variation on a deeper ontological level need not inhibit dialogue and cross-cultural agreements on certain fundamental aspects because different conceptions, rooted within different ontological frameworks, might resonate when they touch on something essentially true for humanity at large. From this perspective, the post-development argument is turned around: to not recognise for instance human dignity as conceptualised in an alternative ontological framework as equally reasonable and therefore fundamentally at par risks reproducing an 'othering' lens and hampers genuine inclusive dialogue. Moreover, Joygrami Muslims seek inclusion in the nation-state, although in reality, community initiatives such as the mission schools may also reproduce their (cultural) exclusion from it.

Thirdly, alternatives to development, often drawing on indigenous non-Western frames and modes of being (such as buen vivir), risk falling into cultural relativism (legitimising other culturally embedded forms of oppression) and a lack of attention to internal ambiguity and contestation, which might too lightly be considered moral mistakes and false consciousness (cf. Artaraz and Calestani 2014). Universal commitments are handles and tools to preclude detrimental inequality (Corbridge 1994; Fabricant 2013; Radcliffe 2011).

For instance, the mission schools appear as a unanimously supported initiative, but it is not unlikely that contesting opinions arise, especially if development gains turn out not to be as equitable or comprehensive as hoped. Deneulin argues that 'there is no separation between religion and development. Development is what adherents to a religion do because of who they are and what they believe in' (Deneulin and Bano 2009, p. 2); But the popularity of Islamic reformism in Joygram should not lead to an easy conclusion that religion is all people want (cf. White and Deneulin 2009 on comparable observations in Bangladesh). Local norms, religious dogma and cultural ideals should be open to public deliberation, because they have always been dynamic and should never be taken as fixed, and are very often subject to power relationships, even if often co-opted by the dominated and oppressed. Religious norms can become prominent because there is a perceived moral vacuum in state-driven development. The projects of (those who assume) religious leadership can turn out for better or worse, but it is particularly worrisome that opportunistic political actors (often the more powerful and/or the wealthier) could appeal to religious norms according to their convenience and possibly hamper the improvement of quality of life of all involved (cf. Chen 1995; Gasper 1996; Nussbaum 1999a, 29ff). In the Joygrami case, an already very patriarchal society, it is predominantly men who can establish a monopoly on development initiatives in the vacuum left by the state. The Islamic reformism, as employed in Joygram, can therefore have severe limitations, particularly when it comes to women's freedom. It has been argued 
above against imposing a secular notion of liberation on religious communities; But the seven values of worthwhile development aforementioned (of which wellbeing, equality, empowerment, human rights and cultural freedom are particularly pertinent) or Martha Nussbaum's list of basic capabilities (2000) could be engaged with from within the religious ontology. These can be handles to the schools to support consistent commitment to the equal dignity of each and every human person and avoid the unequal distribution of development gains.

\section{Dialogue Across the Religious/Secular Binary}

The aim should thus not be to replace translocal development approaches with (religious) post-development alternatives but to allow for engagement with the former to be rooted in religious ontological positions and concepts. Drawing on various transcendental and immanent resources, including alternative conceptions of e.g. the human, freedom and reason, involved parties (concerned citizens, local leaders, state representatives and foreign aid workers) could work together towards a dynamic overlapping consensus as to the nature of worthwhile development.

Nussbaum and Sen (1987) developed a method for the evaluation and criticism of a tradition and its values that would be respectful for cultural integrity and avoids the imposition of external (secular) values, which could helpfully be applied to a religiously inspired ontology. They suggest that evaluation should be internal, using resources from inside the tradition; that it should be immersed rather than detached; and that it should be genuinely critical (1987, p. 15). Most religions, including Islam, offer such space for debate (Mesbahuddin 2010; Nussbaum 2000). Moreover, a process of internal criticism can help determine which values lie at the core and which at the margin of a community's 'existence rationale' (Goulet 1971, pp. 187-191), and which values should therefore lie at the heart of worthwhile development and which could more easily change to this end. Such change should occur according to the principle of moral restraint: religion is recognised as a constitutive dimension of people's life, but to avoid a possible negative impact of religion, its influence should be restricted by the moral claims of the religion itself (Nussbaum 2000). So, rather than a process of secularisation, this is a process of internal reasoning, based on an acknowledgement that engagements with certain religious norms have always changed throughout history in tandem with changes in power relations and material and other circumstances. Apart from more respectful, this would also be more just and more effective than an imposition of an alien ontological notion of being and development. Imposing ideas from outside could result in confusion, fear or reactionary backlash. The latter occurred most famously in India in the Shah Bano case (Benhabib 2002; Nussbaum 2000).

The reinterpretation of religion proposed here allows for a separation of certain non-essential religious values from the ontological basis a religion is entangled in. This separation allows for public debate on which values are supporting worthwhile development and which ones are obstacles. Only when religious and secular ideas of being, fundamental to people's ethical position, are acknowledged as equally reasonable and valuable, certain norms that have become associated with religion, such as 
the norm to pay a dowry or veiling, can be discussed on the basis of internal reasoning and criticism.

There are numerous local notions that could either inhibit or stimulate worthwhile development. The fact that everyone has the same potential to develop gyan is an excellent starting point for a discussion on for example women's ability to plan their own lives. The reformist discourses are not in principle better or worse than more traditional notions of self, but they could fruitfully be included in the debate. The younger generation of women use Islamic reformist ideology to challenge certain norms that undermine their freedoms and rights; For instance the norm that women are not allowed to go to the bazaar is now called a 'cultural' norm that men invented to suppress women, whereas the Islamic reformists preach that men and women have equal rights in Islam. The introduction of the niqab is instead considered a religious instruction that some women choose to follow because it deepens their personal relationship to god. Institutions such as the mission schools resort to this discourse to justify the obligation of the niqab.

The obligation for girl students of the mission school to veil could be criticised as an unequal restriction on women's freedom; But some girls actively choose to veil, and for others perhaps the obligatory uniform is acceptable because at the same time the girls are developing critical autonomy and are being prepared for positions where they will be in a position to choose alternatives more easily. In any case, they have to be granted the dignity to approach these dilemmas on the basis of their own gyan. Because advocating development towards more freedom and choice for women, while rejecting that the source of freedom and choice is in gyan and divine submission, would mean, in local terms, a counterproductive rejection of the freedom to reason altogether.

\section{Conclusions}

A development dialogue that draws on various ontological sources is urgently needed. As it has been argued, there is no qualitative difference between a predominantly secular or religious ontology, and for both it would be valuable to recognise the transcendental sources and fundamental human values that cross such a divide and mobilise these to impact on worthwhile development. Such a demand may still seem a distant reality: not qualitative visions of development but economic growth is still the de facto top priority of most development policy, despite the fact that countries whose governments have pursued aggressive economic growth strategies frequently show negative indicators in many important dimensions, including major increases in inequality (Deneulin and Rakodi 2011, p. 14). But not only is this focus on the economy ineffective, and the disregard of other ways of life a disrespect of human dignity: if the scope of development does not go beyond quantifiable targets, there is a great risk of cultural backlash. A reaction against the imposition of liberalism by 'outsiders' may include disregard of universal human rights agreements and rejection of liberal development paradigms that emphasise freedom and choice. It may open up the opportunity for some religious leaders, opportunists 
and populists to jump in the moral vacuum. In Joygram, the 'West' and modernisation have become synonymous with moral decline, and they 'don't want your freedom' imposed any longer. Here, the moral vacuum is currently being filled by Islamic reformism, which presents itself as an alternative route to modernity (see Pool 2020). The rapid transformations the reformists bring do sometimes, but not always, enhance human flourishing for each and every person no matter their gender or status.

Perhaps, through dialogues and processes of internal reasoning India's reformist Muslims may for instance allow women the same freedoms as men. However, internal criticism requires a sense of security, while Muslims in India are in a vulnerable position (Bilgrami 2011, p. 31). Whenever a dialogue would be initiated, protection from majority oppression and a 'climate of respect and support' for the Muslim community is ever more important (Nussbaum 2000, p. 230). The demoralisation caused by economic inequalities and the loss of identity in the face of cultural globalisation (Meyer and Geschiere 1999) are adding to the vulnerability and a potential unwillingness to destabilise community cohesion. A forced imposition to 'step outside' one's ontological position to reflect on worthwhile development would be counterproductive in this context.

The latter point is proving relevant not only in the Global South but also in the North, where increasing religious and cultural diversity poses a challenge to universal liberal development paradigms. But perhaps it is possible to save worthwhile universal commitments by in fact making them stronger by allowing a deep variation of and conversation between ontological accounts of life and justice to enter into public debate. Indeed, recognising the transcendental sources of our commitments and ideals, whether customarily called religious or secular, could bring us closer to recognising shared values across humanity and finding agreement on a robust set of social justice commitments (Khader and Kosko 2019) or (global) public goods (Deneulin and Townsend 2007; Gasper and Comim 2019) that some development theorists, including myself, consider crucial for harmonious cohabitation and fairly distributed wellbeing in our increasingly diverse but interconnected, globalised and unequal societies and our shared world.

Acknowledgements This project has received funding from the European Union's Horizon 2020 research and innovation programme under Marie Skłodowska-Curie grant agreement no. 707404.

\section{Compliance with Ethical Standards}

Conflict of Interest The author states that there is no conflict of interest.

Open Access This article is licensed under a Creative Commons Attribution 4.0 International License, which permits use, sharing, adaptation, distribution and reproduction in any medium or format, as long as you give appropriate credit to the original author(s) and the source, provide a link to the Creative Commons licence, and indicate if changes were made. The images or other third party material in this article are included in the article's Creative Commons licence, unless indicated otherwise in a credit line to the material. If material is not included in the article's Creative Commons licence and your intended use is not permitted by statutory regulation or exceeds the permitted use, you will need to obtain permission directly from the copyright holder. To view a copy of this licence, visit http://creativecommons.org/licen ses/by/4.0/. 


\section{References}

Alam, M.S. 2010. Social Exclusion of Muslims in India and Deficient Debates about Affirmative Action Suggestions for a New Approach. South Asia Research 30 (1): 43-65.

Alam, M.S., and S. Raju. 2007. Contextualising Inter-, Intra-religious and Gendered Literacy and Educational Disparities in Rural Bihar. Economic and Political Weekly 42: 1613-1622.

Alkire, S. 2000. Valuing Freedoms. Sen's Capability Approach and Poverty Reduction. Oxford: Oxford University Press.

Ansari, I.A. 2006. Political Representation of Muslims in India: 1952-2004. Delhi: Manak.

Artaraz, K., and M. Calestani. 2014. Suma Qamaña in Bolivia Indigenous Understandings of Well-being and Their Contribution to a Post-Neoliberal Paradigm. Latin American Perspectives. https://doi. org/10.1177/0094582X14547501.

Asad, T. 2003. Formations of the Secular: Christianity, Islam, Modernity. Stanford: Stanford University Press.

Bartelink, B., and M.W. Buitelaar. 2006. Religion and Gender in a Dutch Action-Research Project in Yemen. Gender \& Development 14 (3): 351-362.

Benhabib, S. 2002. The Claims of Culture. Princeton: Princeton University Press.

Bhargava, R. 2010. The Promise of India's Secular Democracy. Delhi: Oxford University Press.

Bilgrami, A. 2011. Secularism. Its Content and Context. In SSRC Working Papers. Retrieved from The Immanent Frame website: http://blogs.ssrc.org/tif/2011/10/20/secularism-its-content-and-context/.

Casanova, J. 1994. Public Religions in the Modern World. Chicago: University of Chicago Press.

Chen, M. 1995. A Matter of Survival: Women's Right to Employment in India and Bangladesh. In Women, Culture, and Development: a Study of Human Capabilities, ed. M.C. Nussbaum and J. Glover, 37-57. Oxford: Clarendon.

Clarke, G., M. Jennings, and T. Shaw (eds.). 2007. Development, Civil Society, and Faith-Based Organisations. Bridging the Sacred and the Secular. Basingstoke: Palgrave Macmillan.

Clarke, M. 2013. Handbook of Research on Development and Religion. Northampton, MA: Edward Elgar.

Clarke, M., and D. Titterson. 2016. Islam and Development. Exploring the Invisible Aid Economy. London and New York: Routledge.

Cooper, F., and R. Packard. 1997. International Development and the Social Sciences: Essays in the History and Politics of Knowledge. Berkeley: University of California Press.

Corbridge, S. 1994. Post-marxism and Post-colonialism: the Needs and Rights of Distant Strangers. In Rethinking Social Development: Theory, Research \& Practice, ed. D. Booth, 90-117. Harlow: Longman.

Crocker, D.A. 1991. Toward Development Ethics. World Development 19 (5): 457-483.

Deneulin, S. 2006. The Capability Approach and the Praxis of Development. Basingstoke and New York: Palgrave Macmillan.

Deneulin, S., with M. Bano. 2009. Religion in Development: Rewriting the Secular Script. London and New York: Zed Books.

Deneulin, S., and C. Rakodi. 2011. Revisiting Religion: Development Studies Thirty Years on. World Development 39 (1): 45-54.

Deneulin, S., and N. Townsend. 2007. Public Goods, Global Public Goods, and the Common Good. International Journal of Social Economics 34 (1/2): 19-36.

Devine, J., and S. Deneulin. 2011. Negotiating Religion in Everyday Life: a Critical Exploration of the Relationship between Religion, Choices and Behaviour. Culture and Religion 12 (1): 59-76.

Devine, J., and S. White. 2013. Religion, Politics and the Everyday Moral Order in Bangladesh. Journal of Contemporary Asia 43 (1): 127-147.

Drydyk, J., and L. Keleher. 2018. Routledge Handbook of Development Ethics. Abingdon: Routledge.

Escobar, A. 1995. Encountering Development: the Making and Unmaking of the Third World. Princeton: Princeton University Press.

Fabricant, N. 2013. Good Living for Whom? Bolivia's Climate Justice Movement and the Limitations of Indigenous Cosmovisions. Latin American and Caribbean Ethnic Studies 8 (2): 159-178.

Ferguson, J. 1990. The Anti-politics Machine: Development, Politicization and Democratic Power in Lesotho. Cambridge: Cambridge University Press.

Gasper, D. 1996. Culture and Development Ethics: Needs, Women's Rights, and Western Theories. Development and Change 27 (4): 627-661. 
Gasper, D., and F. Comim. 2019. Public Goods and Public Spirit: Reflections on and Beyond Nussbaum's Political Emotions. In Agency and Democracy in Development Ethics, ed. L. Keleher and S. Kosko. Cambridge: Cambridge University Press.

Gough, I., and J.A. McGregor (eds.). 2007. Wellbeing in Developing Countries. From Theory to Practice. Cambridge: Cambridge University Press.

Goulet, D. 1971. The Cruel Choice: a New Concept in the Theory of Development. New York: Atheneum. Goulet, D. 1995. Development Ethics: a Guide to Theory and Practice. New York: The Apex Press.

Gupta, N. 2009. Reading with Allah: Madrasas in West Bengal. Delhi: Routledge.

Haq, M. 1995. Reflections on Human Development. New York: Oxford University Press.

Hasan, M. 2007. Living with Secularism: the Destiny of India's Muslims. Delhi: Manohar.

Hasan, Z., and R. Menon (eds.). 2005. In a Minority: Essays on Muslim Women in India. Delhi: Oxford University Press.

Jeffery, P., and R. Jeffery. 2006. Confronting Saffron Demography: Religion, Fertility, and Women's Status in India. Gurgaon: Three Essays Collective.

Jeffrey, C., P. Jeffery, and R. Jeffery. 2008. Degrees without Freedom? Education, Masculinities, and Unemployment in North India. Stanford: Stanford University Press.

Khader, S.J., and S.J. Kosko. 2019. 'Reason to Value': Process, Opportunity, and Perfectionism in the Capability Approach. In Agency and Democracy in Development Ethics, ed. L. Keleher and S. Kosko. Cambridge: Cambridge University Press.

Khan, S. 2007. Negotiating the Mohalla: Exclusion, Identity and Muslim Women in Mumbai. Economic and Political Weekly 42: 1527-1533.

Kirmani, N. 2008. Constructing 'The Other': Narrating Religious Boundaries in Zakir Nagar. Contemporary South Asia 16 (4): 397-412.

Lunn, J. 2009. The Role of Religion, Spirituality and Faith in Development: a Critical Theory Approach. Third World Quarterly 30 (5): 937-951.

Mesbahuddin, T. 2010. Religion in Development: an Islamic Model Emerging in Bangladesh. Journal of South Asian Development 5 (2): 221-241.

Meyer, B., and P. Geschiere (eds.). 1999. Globalization and Identity: Dialectics of Flow and Closure. Malden: Blackwell.

Narayan, D., R. Chamber, M. Shah, and P. Petersch. 2000. Voices of the Poor. Crying Out for Change. New York: Oxford University Press for the World Bank.

Nussbaum, M.C. 1999a. Sex and Social Justice. Oxford: Oxford University Press.

Nussbaum, M.C. 1999b. A Plea for Difficulty. In Is Multiculturalism Bad for Women?, ed. J. Cohen, M. Howard, and M.C. Nussbaum, 105-114. Princeton: Princeton University Press.

Nussbaum, M.C. 2000. Women and Human Development: the Capabilities Approach. Cambridge: Cambridge University Press.

Nussbaum, M.C. 2009. The Clash within. Democracy, Religious Violence, and India's Future. Boston: Belknap.

Nussbaum, M.C. 2010. Not for Profit: Why Democracy Needs the Humanities. Princeton: Princeton University Press.

Nussbaum, M.C. 2011. Creating Capabilities. The Human Development Approach. Boston: Harvard University Press.

Nussbaum, M and A. Sen. 1987. Internal Criticism and Indian Rationalist Traditions. WIDER Working Papers, WP30.

Pool, F.W. 2016. The Ethical Life of Muslims in Secular India: Islamic Reformism in West Bengal. London School of Economics, PhD Thesis.

Pool, F.W. 2020. Within and Beyond Modernity: Lived Experiences and Ethical Interruptions of the Tablighi Jamaat in West Bengal. Modern Asian Studies.

Radcliffe, S.A. 2011. Development for a Postneoliberal Era? Sumak Kawsay, Living Well and the Limits to Decolonisation in Ecuador. Geoforum 43: 240-249.

Robeyns, I. 2017. Wellbeing, Freedom and Social Justice. The Capability Approach Re-examined. Cambridge: Open Books.

Sachar Committee. 2006. Sachar Committee Report Social, Economic and Educational Status of the Muslim Community in India. New Delhi: Government of India, Cabinet Secretariat, Report of the Prime Minister's High Level Committee.

Sachs, W. 1992. The Development Dictionary. A Guide to Knowledge as Power. London: Zed Books. Sen, A. 1999. Development as Freedom. Oxford: Oxford University Press.

Sen, A. 2006. Identity and Violence. Harmondsworth: Penguin. 
Sen, A. 2014. The Relevance of Buddha. Ethics \& International Affairs 28: 15-27.

Shariff, A. 2012. Inclusive Development in India: A Post-Sachar Perspective. In US-India Policy Institute Occassional Paper.

Social Network for Assistance to People (SNAP). 2014. Preliminary Public Report on the Status of Muslims in West Bengal. Kolkata: Association SNAP and Guidance Guild.

Tyndale, W. 2006. Visions of Development. Aldershot: Ashgate.

Venkatesan, S., and T. Yarrow (eds.). 2012. Differentiating Development. Beyond an Anthropology of Critique. Oxford: Berghahn Books.

Watene, K., and J. Drydyk. 2016. Theorizing Justice. Critical Insights and Future Directions. London: Rowman \& Littlefield.

White, S. 2011. Religion, Development and Wellbeing in India and Bangladesh. Birmingham: Religions and Development Research Program.

White, S. 2015. Introduction. The Many Faces of Wellbeing. In Cultures of Wellbeing: Methods, Place, Policy, ed. S. White, 1-44. Basingstoke: Palgrave Macmillan.

White, S., and S. Deneulin. 2009. Culture and Religion. In An Introduction to the Human Development and Capability Approach Freedom and Agency, ed. S. Deneulin and L. Shahani, 246-272. London: Earthscan.

Williams, P. 2011. An Absent Presence: Experiences of the 'Welfare State' in an Indian Muslim Mohallā. Contemporary South Asia 19 (3): 263-280.

Williams, P. 2012. India's Muslims, Lived Secularism and Realising Citizenship. Citizenship Studies 16 (8): 979-995.

Wilson, E. 2010. Beyond Dualism: Expanded Understandings of Religion and Global Justice. International Studies Quarterly 54 (3): 733-754.

Wilson, E. 2014. Faith-Based Organisations and Post-secularism in Contemporary International Relations. In Towards a Postsecular International Relations: New Forms of Community, Identity and Power (Culture and Religion in International Relations), ed. L. Mavelli, 219-241. Basingstoke: Palgrave MacMillan.

Publisher's Note Springer Nature remains neutral with regard to jurisdictional claims in published maps and institutional affiliations. 